Journal of Urban and Regional Analysis, vol. XIII, 2, 2021, p. 301 - 322

https://doi.org/10.37043/JURA.2021.13.2.6

\title{
INCLUSIVE URBANISATION? A STUDY OF INDIAN SLUMS
}

\author{
Somenath GHOSH ${ }^{1}$, Pallabi SETH ${ }^{2}$, Saumya CHAKRABARTI' \\ ${ }^{1}$ Visva-Bharati University, Bolpur, India \\ ${ }^{2}$ Fondazione L'Albero Della Vita, Kolkata, India
}

\begin{abstract}
The proliferation of slums always questions the process of inclusive urbanisation in developing countries. Given this perspective, the study aims to see the changing pattern of urbanisation in India comparing the level, concentration and growth of slum and urban populations over time. Furthermore, it intends to see the relationships of different economic indicators with the level and concentration of urban and slum population in order to determine the inclusiveness of Indian cities. The study incorporated descriptive and inferential statistical analysis using Indian state-level data on urban and slum population and different economic indicators for 2001 and 2011. The study finds an increasing level of slum population compared to the urban population in most Indian states, while shifting the concentration of slum population from high-income to newly growing states. We also evidence the positive impact of economic inequality on the expansion of slum population. The study concludes that the process of economic growth with exclusionary urbanisation generates urban inequality, which helps to persist the slums.
\end{abstract}

Key Words: inclusive urbanization, slum dwellers, economic inequality, logarithmic regression.

\section{Introduction}

The whole world is now mesmerized with the concept of "inclusive city". It talks about the cities that must have the capacity to generate spatial, social and economic inclusion of the marginal or poor people with its growth and development (Armendaris 2015). However, despite the efforts for inclusive urbanization, exclusion in cities is seen as growing at a high rate in many developing countries, as influxes of poor migrants to the cities are widely noticed (Tacoli et al. 2015). It is already evident across the globe that the slum population of urban areas, specifically in developing countries, has increased tremendously and it has firstly been estimated to rise to 2 billion by 2020 (UN-HABITAT 2003). However, the latest official data is of 863 million people for the global urban slum population (UN-HABITAT 2013). So, these facts persuasively restrain us to nullify the perception of the 'urbanization of poverty' (Piel 1997), and they also prevent us from accepting the notion of the inclusiveness of cities. Thus, the basic argument in this paper affirms the concept that the expansion of slums is one of the symptoms of exclusionary urbanisation. Our study attempts to explore the extent of increase in slum dwellers and to find the possible determinants of their existence and spread.

In recent times, India is experiencing a high urban-centric economic growth ${ }^{1}$ with rapid urbanisation. The country's urban population has been increasing speedily ${ }^{2}$ and it is projected to reach 590 million people by 2030 (Sankhe et al. 2010). But, beside the rise in urban population, the population of the slums has also increased rapidly from 42.5 million in 2001 to 65.5 million in 2011 and, even worse, 0.9 million urban people are counted as houseless (Government of India 2001, Government of India 2011). Therefore, a widespread view has emerged among many researchers, development practitioners and policy analysts that poverty is urbanising in this country, and it is moving far away from attaining inclusive urban growth. Moreover, the recent trends of high economic growth without a significant 
formal sector employment generation in India also do not endorse inclusive growth (Chakrabarti 2016).

According to modernisation theorists, poverty and slums are temporary phenomena in cities. They have argued that the process of urbanisation has a natural ability to eradicate the problems of poverty and slums, with the help of economic growth and modernisation methods (Frankenhoff 1967, Turner 1969, World Bank 2009, Glaeser 2011). Accordingly, inclusive urbanisation is considered to take place without any push of development policies and programmes. And, following this view, planners of many developing countries, including India, had reserved little provision for urban development in their earlier development plans. However, later, it was noted that urban poverty and slums were on the rise, mainly due to the lack of a formal sector employment and the inability of the poor to work in the formal sector (Stokes 1963, Harris and Todaro 1970). Therefore, from 1980s, to address this problem, the Government of India had emphasised on the alleviation of poverty from urban areas through development programs for achieving inclusive and comprehensive urbanisation $^{3}$ (UN-HABITAT 2009, Mishra and Dasgupta 2014).

But, despite such policies and programs, discrimination and exclusion continue to prevail in urban India, as the increase in consumption inequality in urban areas depicts the unequal urban process (Sarkar and Mehta 2010). Concurrently, the uneven distribution of the economic growth process in urban areas encourages socio-spatial inequality (Ahmed et al. 2011), and socio-economic disparities are visible between the tier-I and tier-II cities in India (Kundu and Samanta 2011). However, approaching the issue from a different perspective, Harvey (2008) has blamed the urban transformation behind such disparity, and he criticised this new trend, claiming it as an exclusionary process by which many slums and squatter settlements have not only been generated but they also get displaced or evicted ${ }^{5}$ through the process. The recent idea of creating world-class cities in India follows a certain spatial change - the elites have acquired peri-urban areas and a special economic zone is created to attract global capital; this also does not ensure the process of inclusion of the poor (Roy 2014). The creation of World-class cities rather results in the dispossession and displacement of the poor.

On one hand, a study (Marx et al. 2013) analysed the predominance of slums from a different perspective. It argued that the persistence of slums is a result of the existing policy gaps and poverty traps. On the other hand, the lack of human capital formation and the investment inertia have been proposed as factors that are confining slum dwellers into a poverty trap (Duflo et al. 2012). And there is a conflict of action between the formal policy proposal and the involvement of local private actors, causing failure to ensure an effective policy action for the improvement of slum dwellers (Fox 2014). The process of rapid urbanisation in the less developed countries is posturing challenges in their governance. The growing cities of many developing countries lack a proper institutional mechanism to keep the things in order so that the inclusiveness of cities to be enhanced (Henderson and Turner 2020).

The regional diversity of urbanisation processes around the world occurs due to a variety of factors. The causes of urbanisation in South Asia are quite different from those in SubSaharan Africa (Lall et al. 2017, Akbar et al. 2018). Several studies observed that, unlike many other countries, India's process of urbanisation follows the classic Roback model of rural to urban migration due to regional inequality (Chauvin et al. 2017). So far, many studies have been conducted to examine the trends of urbanisation in India. One among them (Sankhe et al. 2010) uncovered the realities of Indian cities and it discussed their prospects while it emphasised on the policies which may lead India to achieve inclusive urbanisation. But it hardly discussed the present condition of urbanisation concerning the growth of slum dwellers (Sankhe et al. 2010). Besides, the report of the Indian Institute for Human Settlements (2014) on 'cities as engine of inclusive development' has demonstrated the relations between urbanisation, employment generation, economic growth and human 
development, in order to understand how cities in India are getting inclusive. However, the report has left further the scope of analysing the relationships between urbanisation and other economic indicators in order to assess inclusive urban growth (Institute for Human Settlements 2014). Moreover, until now, few studies have been conducted to explore the possibilities regarding the expansion of slum population due to the influence of different economic indicators at macro level, specifically from the Indian perspective. Hence, the above arguments and gaps induce us to raise questions on the current process of urbanisation and they encourage us to re-examine the present changing trend and pattern of urbanisation that India is undergoing. The relation between urbanisation and the essential economic indicators has also been worth noting. Besides, we specifically felt the need of studying the changing trends of the slum population with urbanisation and to find out which probable factors are influencing it, in order to address our primary issues.

Thus, the article aims to understand the process of urbanisation (whether it is inclusive) by comparing the proportion of urban and slum population in the total of the population and the urban population respectively along with their growth rates. And the study intends to explore the share of urban and slum population of the regions out of the total urban and slum population of the country. Next, as a digression, the study further purposes to enquire into the inclusiveness of cities through finding the relationships between urbanisation and the relevant economic indicators. Finally, the paper focuses to look at the influence or impact of economic indicators on the expansion of slum population.

\section{Methodology}

The study employs Indian state-level data for two rounds: 2001 and 2011 (Government of India 2001, Government of India 2011). We consider 15 major states ${ }^{6}$ that constitute more than $85 \%$ and $90 \%$ of the total urban and slum population of India respectively, for both rounds (Fig. 1).

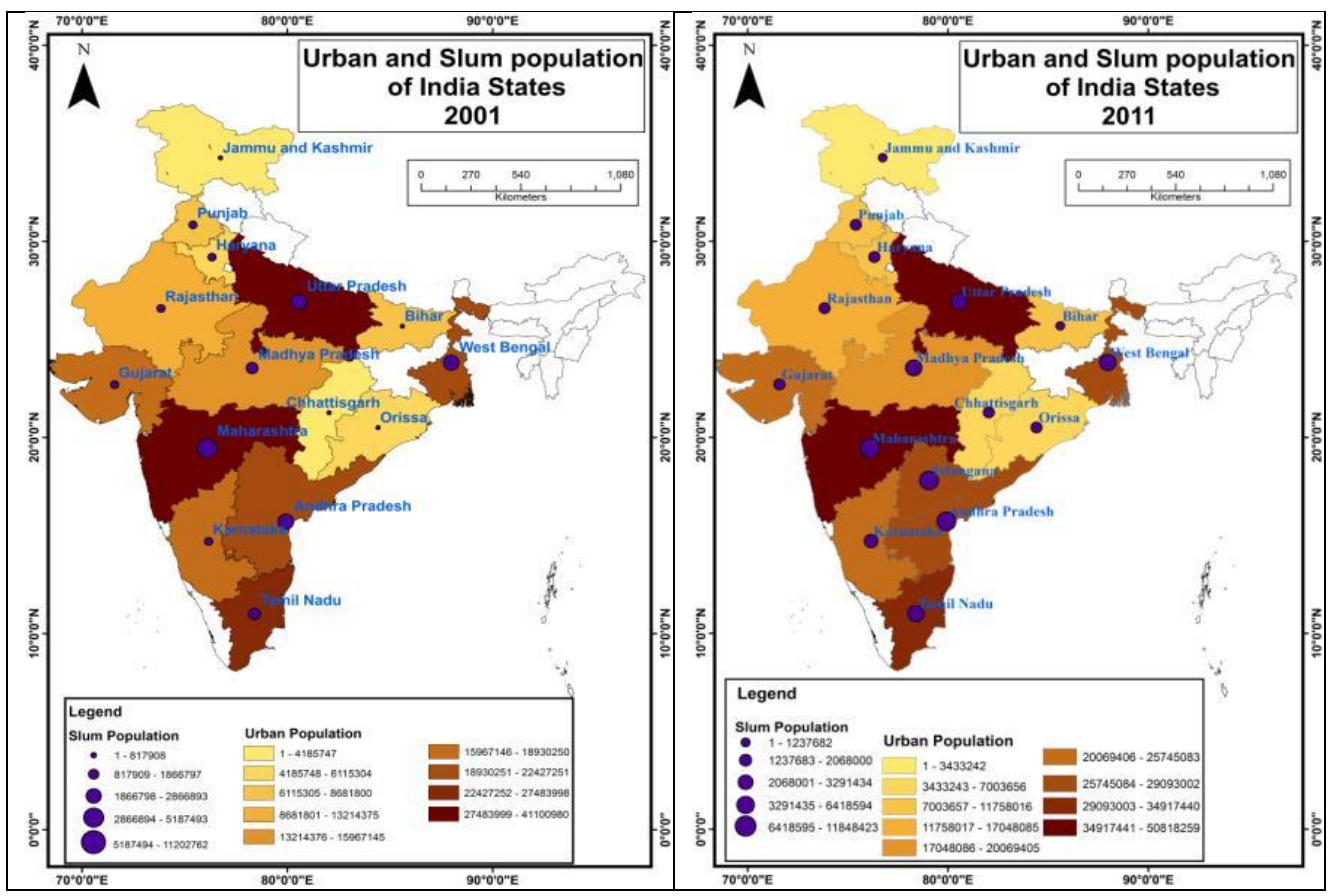

Fig. 1 - The Indian States' urban and slum population

Source ${ }^{9}$ : the authors' estimation 
The data for the analysis (Table 1 ) was collected from the census (Government of India 2001, Government of India 2011), from the reports of the Reserve Bank of India (2021), the National Sample Survey Office $(2011,2014)$, the National Sample Survey Organisation (2001a, 2001b, 2003, 2012) and the databook of the Planning Commission of India (2014). We used the statistical software Stata 8 for the analysis.

Table 1

List of variables with data source

\begin{tabular}{|c|c|c|c|}
\hline Variables & Indicators & Abbreviation & Data Source \\
\hline Slum Population & & SlumPop & Census \\
\hline Urban Population & & UrbanPop & Census \\
\hline $\begin{array}{l}\text { Share of Urban } \\
\text { Population to Total } \\
\text { Population }\end{array}$ & $\begin{array}{l}\text { Level of } \\
\text { Urbanisation }\end{array}$ & Urban-Level & Census \\
\hline $\begin{array}{l}\text { Share of Urban } \\
\text { population of the states } \\
\text { out of the total urban } \\
\text { population of India }\end{array}$ & $\begin{array}{l}\text { Concentration of } \\
\text { Urbanisation }\end{array}$ & $\begin{array}{l}\text { Urban- } \\
\text { Concentration }\end{array}$ & Census \\
\hline $\begin{array}{l}\text { Share of slum population } \\
\text { out of urban population }\end{array}$ & $\begin{array}{l}\text { Level of Slum } \\
\text { dwellers/population }\end{array}$ & Slum-Level & Census \\
\hline $\begin{array}{l}\text { Share of slum population } \\
\text { of the states out of the } \\
\text { total slum population of } \\
\text { India }\end{array}$ & $\begin{array}{l}\text { Concentration of } \\
\text { slum } \\
\text { dwellers/population }\end{array}$ & Slum-Concentration & Census \\
\hline $\begin{array}{l}\text { Urban consumption } \\
\text { inequality (Gini } \\
\text { coefficient) }\end{array}$ & $\begin{array}{l}\text { Urban Economic } \\
\text { Inequality }\end{array}$ & $\begin{array}{l}\text { Urban-Economic- } \\
\text { Inequality }\end{array}$ & $\begin{array}{l}\text { Planning Commission } \\
\text { databook }\end{array}$ \\
\hline $\begin{array}{l}\text { Monthly Per capita } \\
\text { Consumption } \\
\text { Expenditure in the Urban }\end{array}$ & $\begin{array}{l}\text { Cost of Living in the } \\
\text { Urban }\end{array}$ & $\begin{array}{l}\text { Cost-of-Living- } \\
\text { Urban }\end{array}$ & $\begin{array}{l}\text { National Sample Survey } \\
\text { Organisation, National } \\
\text { Sample Survey Office }\end{array}$ \\
\hline $\begin{array}{l}\text { Workforce Participation } \\
\text { Rate in the Urban }\end{array}$ & $\begin{array}{l}\text { Employment } \\
\text { Opportunities in the } \\
\text { Urban }\end{array}$ & Urban-Employability & Census \\
\hline $\begin{array}{l}\text { Casual worker's Wage } \\
\text { Rate in Urban areas }\end{array}$ & $\begin{array}{l}\text { Wage rate in Urban } \\
\text { areas }\end{array}$ & Wage-Rate-Urban & $\begin{array}{l}\text { National Sample Survey } \\
\text { Organisation }\end{array}$ \\
\hline $\begin{array}{l}\text { Urban-rural casual } \\
\text { worker's Wage rate Gap }\end{array}$ & $\begin{array}{l}\text { Urban-rural Wage } \\
\text { Rate Gap }\end{array}$ & $\begin{array}{l}\text { Urban-rural-Wage- } \\
\text { Rate-Gap }\end{array}$ & $\begin{array}{l}\text { National Sample Survey } \\
\text { Organisation, National } \\
\text { Sample Survey Office }\end{array}$ \\
\hline $\begin{array}{l}\text { Per capita Urban Net } \\
\text { State Domestic Product } \\
\text { (Urban-NSDP) }\end{array}$ & $\begin{array}{l}\text { Urban Economic } \\
\text { Growth }\end{array}$ & Urban-NSDP & Reserve Bank of India \\
\hline $\begin{array}{l}\text { Urban informal workers } \\
\text { out of the total workers of } \\
\text { the urban }\end{array}$ & $\begin{array}{l}\text { Share of urban } \\
\text { informal } \\
\text { employment }\end{array}$ & Urban-Informality & $\begin{array}{l}\text { National Sample Survey } \\
\text { Organisation }\end{array}$ \\
\hline
\end{tabular}

For the analysis, we took the variables as described below:

a) In the first part of the study, we measured the level, concentration and growth of the urban as well as slum dwellers. We have considered the variables: share of urban population to total, share of urban population of the states out of total urban population in India and the decadal growth of urban population, which are applied for measuring the level, the concentration and growth of the urban population respectively. Similarly, the level, concentration and pace of increase of the slum population have been measured by the variables: share of slum population to urban population, share of slum population of the states out of the total slum population of India and the decadal growth of slum population respectively. This has been illustrated with the help of a table and thereafter, paired t-tests have been done to articulate whether the difference of mean 
between the periods is significant for the levels of slum and urban population. And an independent sample t-test has been done to find the significant mean difference between the growth rate of slum and urban population.

b) In the second part, we examine the relationships between the level of the urban population and a few selected economic indicators, like the urban consumption inequality, the urban cost of living, employment opportunities in urban areas, urban wage rates ${ }^{7}$ and the share of slum population out of the urban population. We also show the relationships between the concentration of urban population and the same economic indicators. We take the Gini-Coefficient and the Monthly Per Capita Expenditure (MPCE) as proxies for measuring the urban consumption inequality and the cost of living respectively. We also select the workforce participation rate as a proxy for the employment opportunity. In this part, the relationships have been shown with the help of line diagrams and fitted lines where we placed the variables indicating the urbanisation along the $\mathrm{X}$-axis and we put other indicators along the $\mathrm{Y}$-axis to obtain the visual representation of the influence of urbanisation on the economic indicators for 2001 and 2011 separately (Table 2).

c) The relationships between the level and concentration of the slum population and of the same economic indicators, except the urban wage rates, have been observed. Instead of the variable of urban wage rate, we have considered the urban-rural ${ }^{8}$ wage rate gap to see the relationships with the level and concentration of the slum population. Similar to the previous exercise, the relationships have been also shown with the help of line diagrams. But here the influence has been predicted by the economic indicators (along $\mathrm{X}$-axis) on the variables indicating the level and concentration of slum dwellers ( $\mathrm{Y}$-axis) for the same years separately. Apart from the relationships of the main economic indicators in the study, as mentioned above, we have also considered the Net State Domestic Product (NSDP) as a representative of economic expansion, in order to get some connecting relationships between economic growth and some of the previously stated indicators.

d) Along with these relationships, the paper looks at correlations to generate a more meaningful understanding of the changing relationships between the variables, over time. Here, we have noted the difference in the correlation value $(r)$ for the years to identify the changing direction (either positive or negative) of the relationships of the variables. Lastly, two regression models have been developed to find out the impacts of the economic indicators on the slum population and its concentration.

Table 2

Methodology of charts

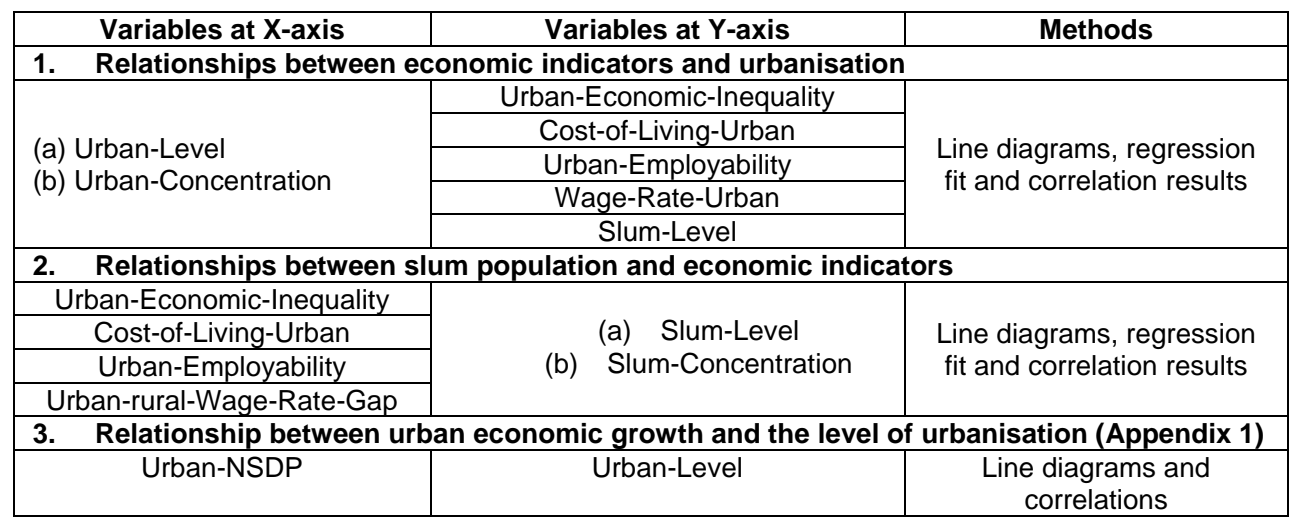




\section{Results}

\section{Level, concentration and growth of urban and slum population: a state-level analysis}

Urbanisation is a multi-aspect and changing process (Davis 1965). Among the multiple contributing factors, economic ones are important. Historically, urban centres were found to be originated mostly around factories or industries, whereas, at present, the urban has no specific centre; several factors induce cities to expand to big urban centres. Apart from the natural growth of population in the cities, rural to urban migration for better employment or living has prompted congestions at urban areas and the expansion of slum population, in contrast. The maps below show the slum and urban population of the analysed states. And there is a significant increase in the level of the urban and slum population over time for India (and also for many states) - from $27.86 \%$ and $14.88 \%$ in 2001 , to $31.14 \%$ and $17.37 \%$ in 2011 respectively (Table 3 ). The result of the paired t-test shows, in both cases, that the increase of their level is significant; it is similar for the growth of both populations, but the growth of slum population $(53.82 \%)$ is almost twice than that of the urban population $(31.8 \%)$, while the average difference between the two growth rates is significant.

Level, concentration and growth of

Table 3 urban and slum populations (2001 and 2011)

\begin{tabular}{|c|c|c|c|c|c|c|c|c|c|c|}
\hline \multirow{2}{*}{ State ${ }^{6}$} & \multicolumn{2}{|c|}{ Urban-Level } & \multicolumn{2}{|c|}{ Slum-Level } & \multicolumn{2}{|c|}{$\begin{array}{c}\text { Urban- } \\
\text { Concentration }\end{array}$} & \multicolumn{2}{|c|}{$\begin{array}{c}\text { Slum- } \\
\text { Concentration }\end{array}$} & \multirow{2}{*}{$\begin{array}{l}\text { Growth of } \\
\text { urban } \\
\text { population } \\
\text { (Decadal } \\
\text { growth) }\end{array}$} & \multirow{2}{*}{$\begin{array}{l}\text { Growth of } \\
\text { slum } \\
\text { population } \\
\text { (Decadal } \\
\text { growth) }\end{array}$} \\
\hline & 2001 & 2011 & 2001 & 2011 & 2001 & 2011 & 2001 & 2011 & & \\
\hline India & 27.86 & 31.14 & 14.88 & 17.37 & & & & & 31.8 & 53.82 \\
\hline J\&K & 24.99 & 27.38 & 10.67 & 19.28 & 0.9 & 0.9 & 0.6 & 1 & 36.42 & 146.57 \\
\hline Punjab & 34.02 & 37.48 & 14.03 & 14.04 & 2.9 & 2.8 & 2.7 & 2.2 & 25.86 & 25.95 \\
\hline Haryana & 29.01 & 34.88 & 23.23 & 18.8 & 2.1 & 2.3 & 3.3 & 2.5 & 44.59 & 17.03 \\
\hline Rajasthan & 23.4 & 24.87 & 9.79 & 12.13 & 4.6 & 4.5 & 3 & 3.2 & 29.01 & 59.8 \\
\hline UP & 20.8 & 22.27 & 12.73 & 14.02 & 12.1 & 11.8 & 10.3 & 9.5 & 28.82 & 41.97 \\
\hline Bihar & 10.48 & 11.29 & 6.12 & 10.53 & 3 & 3.1 & 1.2 & 1.9 & 35.43 & 132.87 \\
\hline WB & 27.96 & 31.87 & 18.35 & 22.06 & 7.8 & 7.7 & 9.7 & 9.8 & 29.72 & 55.94 \\
\hline Orissa & 15.03 & 16.69 & 11.42 & 22.28 & 1.9 & 1.9 & 1.5 & 2.4 & 26.94 & 147.67 \\
\hline Chhattisgarh & 20.13 & 23.24 & 19.54 & 31.98 & 1.5 & 1.6 & 1.9 & 2.9 & 41.84 & 132.17 \\
\hline MP & 26.44 & 27.63 & 15.14 & 28.35 & 5.6 & 5.3 & 5.7 & 8.7 & 25.69 & 135.37 \\
\hline Gujarat & 37.41 & 42.6 & 9.86 & 6.53 & 6.6 & 6.8 & 4.4 & 2.6 & 36 & -10 \\
\hline Maharashtra & 42.48 & 45.22 & 27.26 & 23.32 & 14.4 & 13.5 & 26.3 & 18.1 & 23.64 & 5.76 \\
\hline $\mathrm{AP}$ & 27.48 & 33.36 & 24.93 & 36.1 & 7.3 & 7.5 & 12.2 & 15.6 & 35.61 & 96.37 \\
\hline Karnataka & 34.06 & 38.67 & 7.81 & 13.93 & 6.3 & 6.3 & 3.3 & 5 & 31.54 & 134.6 \\
\hline $\mathrm{TN}$ & 44.25 & 48.4 & 10.43 & 16.61 & 9.6 & 9.3 & 6.7 & 8.9 & 27.05 & 102.26 \\
\hline Mean & 27.9 & 31.1 & 14.8 & 19.2 & 5.8 & 5.7 & 6.2 & 6.3 & 31.9 & 79.9 \\
\hline$S D$ & 9.2 & 10.2 & 6.3 & 7.9 & 4 & 3.8 & 6.6 & 5.3 & 6 & 54.7 \\
\hline$t$-test (sig) & 7.76 & $0.00)$ & 3.08 & .003) & & & & & & 001) \\
\hline
\end{tabular}

Source: the authors' estimation, using the census data (Government of India 2001, Government of India 2011) 
The level of the urban or slum population has been widely used as a measure for urbanisation; however, it there are limitations for measuring the regional/state-level thickening of the urban and slum population. So, we introduced another important measure, i.e., the concentration of the urban and slum population for measuring the extent of concentration of those populations across the Indian states. Unlike the urban population, the state-wise concentration of the slum population differs over time. For instance, the concentration of slum population in Maharashtra and Gujarat has reduced, whereas it increased in AP, TN and Karnataka.

The level of urban population has increased significantly in Punjab and Haryana over time, whereas in J\&K, Rajasthan and UP, the level of slum population has increased. The concentration of urban and slum population has changed marginally over time. The growth of slum population is higher than that of the urban population for J\&K, Punjab, UP and Rajasthan. Since the late ' 90 s, the tertiary and secondary sectors started contributing more than the primary sector in Punjab and Haryana, leading to a steady growth in the level of urban population. However, their pattern of urbanisation was different. Most of the rural pockets of Haryana experiencing urbanism ${ }^{10}$ (Singh and Singh 2013) might have induced the formation of small towns (Government of India 2001, Government of India 2011) since 2000 , with less slum population compared to the urban population. Moreover, the rising outmigration of slum dwellers to the State Capital and the National Capital from different districts of Haryana may contribute to decreasing the level/concentration of slum population in the state. Urbanisation in Punjab is spatially dispersed with the growth of small towns around rural hinterlands and few metro cities (Singh and Singh 2014) attracting a huge influx of rural agricultural labours from different parts of Punjab and India. Besides, the infrastructure development increased the daily commute between villages and small towns and between small towns and big cities. Probably, it has resulted in a slow-paced change in the level and concentration of slum population.

The laggard state Bihar witnessed a huge increment in the level of slum population between 2001 and 2011, despite having the lowest level of urban population among all states. With the initiation of a new political regime since 2005, Bihar's economy experienced an unprecedented growth driven by the secondary (construction, manufacturing) and tertiary (communication, tourism, banking and insurance) sectors. Along with that, there was an improper urban planning attributed to the growth of existing cities and the conversion of big villages into new towns. Concurrently, the neglecting attitude of the state in urban policymaking and the poor rural-urban transportation triggered in an overwhelming growth of slums $(132.87 \%)$ in the cities.

Orissa, MP and Chhattisgarh experienced a similar trend like Bihar. The level, concentration and growth of slum population are higher than that of the urban population in 2011. The tribal populations of these states have been caught in the crossfire between acute poverty and inherent political instability; thus, they have often migrated for alternative livelihood opportunities. However, the migration has become increasingly intra-state (Government of India 2001, Government of India 2011), which is one of the reasons pushing the slum population up within these states despite the low level, concentration and growth of the urban population. On the contrary, instead of a higher level of urban population in both periods, WB witnessed a low level of slum population in 2011. The lack of job opportunities because of withering industries (Lahiri 2016) aggravated outbound migration in WB, contributing to a sluggish increase in the level, concentration and growth of slum population.

The rich states of Maharashtra and Gujarat have a very high level of urban population in both periods. Though Maharashtra retained a very high level and concentration of both populations in 2011, it observed a fall in all the above-mentioned aspects since 2001, probably because of the low expansion ${ }^{11}$ of slum population in the newly formed urban areas. Does reverse migration to the suburbs (the gathering of slums around the urbancore), because of the industrialisation of the suburbs and peripheries and of the de- 
industrialisation of the metropolitan core (World Bank 2013), reduce the slum population in cities too? - this requires further attention. Much research (Housing and Land Rights Network 2014) has also referred to the eviction of slum dwellers from cities to the suburbs/peripheries. Furthermore, the ever-increasing out-migration from Maharashtra (Edwin 2019) may have inculpated the lowering of the slum population in urban areas. The level and concentration of both populations are significantly lower in Gujarat than that of Maharashtra in 2011 and all these aspects witnessed deterioration since 2001. Strikingly, the Gujarat's growth of urban population is significantly higher than that of Maharashtra, but it has a negative growth of the slum population. Gujarat encounters decentralised urbanisation with numerous small and medium-sized units receiving huge inter-state migrants (John 2019). Alike Maharashtra, the high out-migration has become pivotal, reducing the level and concentration of the slum population here (Edwin 2019). Whether the in-situ slum development projects (Bhatkal et al. 2015), undertaken by different urban bodies, have contributed the same, it requires further exploration.

AP, Karnataka and TN witnessed a very high level and moderate concentration of urban population in 2001, with a significant increase in 2011. On the contrary, the level and concentration of the slum population are very high in AP compared to Karnataka and TN, but the growth of slum population in AP is less than that of Karnataka and TN. Industrial development can be considered as one of the drivers of decentralised urbanisation in TN (Kolappan 2016), whereas the urban is centred around a few regions of AP. The very high level and concentration of slum population in AP may attribute to ineffective urban planning in cities for accommodating the rural-urban migration (Rohit 2013).

The above sub-national/regional analysis points out increasing footsteps for the slums in Indian cities ${ }^{12}$, despite the government initiatives for its prevention. Therefore, the urbanisation of India seems increasingly exclusionary. Economic inequality has increased (Planning Commission of India 2014) with a structural change in urbanisation which may forbid cities to become inclusive. So, in the following section, we try to explore some relations in order to interrogate more on the inclusive urbanisation of India.

\section{Relationship between economic indicators and urbanisation: a digression}

We assume that the ongoing process of urbanisation in India has been amplifying the urbaninequality and the urban cost of living along with an enhanced employability; it could have possibly increased the inequality between the wage rates too. So, before exploring how these economic indicators are affecting the expansion of the slum population, we seek to explore the influence of urbanisation on these indicators as a separate issue of discussion.

As an outcome of the recent urbanisation process in India, wealth has been accumulating only in a few hands, mainly due to the improper distribution of the economic growth benefit (Sengupta et al. 2008, Sarkar and Mehta 2010). Modern technology-led economic growth in the urban areas only demands skilled workers creating a distinction between the skilled and the unskilled workers in terms of wages or remunerations (Mukherjee 2007). The skilled workers and sophisticated managers are paid high salaries and so, they possess the capacity to spend more compared to the low-salaried or the informal workers. This has differentiated them in terms of living standards, and it therefore generated a stark inequality in a single urban space. Furthermore, in the process of urbanisation, the rich are getting the opportunity to invest their wealth for a better return whereas a poor cannot, which has created a significant gap between the wealthy and the poor. So, there is a high possibility of an increase in urban inequality with the current urbanisation in India.

We see that the cost of living in urban areas is high compared to the rural areas and the process of urbanisation has been continuously raising this cost of living further. Perhaps the rich in urban areas can demand and buy goods at a higher price, thereby the cost of living in 
the city increases. To meet the diversified needs of the rich, various high-value commodities are being produced, which is a prominent characteristic of urbanisation.

The trends show that the scope for employment got boosted in urban areas but mostly in the informal sector, as the expansionary process of urbanisation has attracted many informal constructions and casual workers, petty businessmen, hawkers, and also people involved in petty services (Harris and Todaro 1970, Mazumdar 1976). The wage rates in urban areas are relatively higher than the rural counterparts but the wage rates are still highly unequal. Hence, it would be worth exploring the relationships between urbanisation and employability and between urbanisation and the casual worker's wage rate.

We have considered both the level and concentration of the urban population to see their relationships separately with the economic indicators, by the help of the line diagram, regression fit and correlations for two periods (2001 and 2011). We find no such relationships between the Urban Economic Inequality and the Level of Urban Population in both periods (Fig. 2), whereas the relationship between Urban Economic Inequality and Concentration of Urban Population is weakly positive in both periods (Fig. 3). However, in both cases, we find that the relationships are becoming positive over time (Table 4). Besides, we find indirect relationships between the Level of Urban Population and the Urban Economic Inequality using the Per capita urban Net State Domestic Product as a proxy of urban economic growth. This entails that the growth process taking place in urban areas may deepen economic inequality.

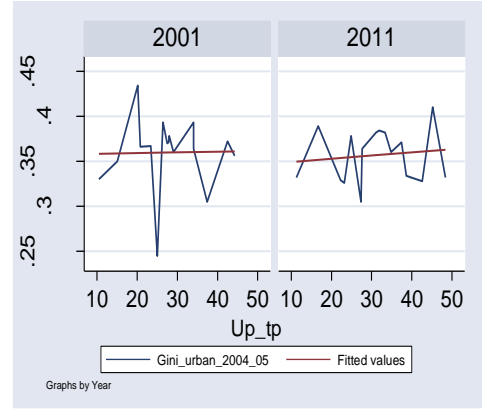

2.1 Association between

Urban-Economic-Inequality and Urban-Leve

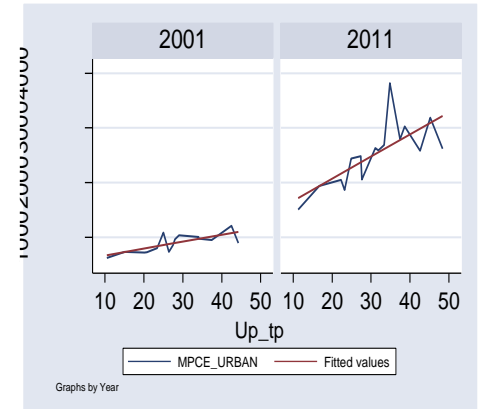

2.2. Association between Cost-ofLiving-Urban and Urban-Level

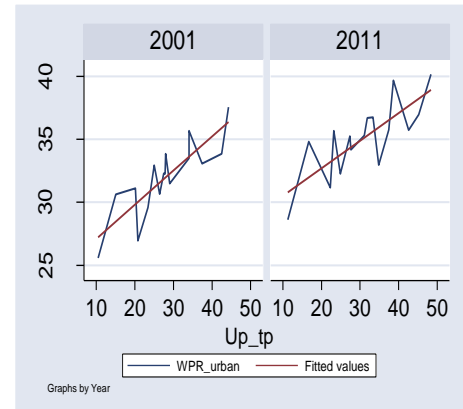

2.3. Association between Urban-Employability and UrbanLevel

For all charts, $X$-axis: Urban-Level

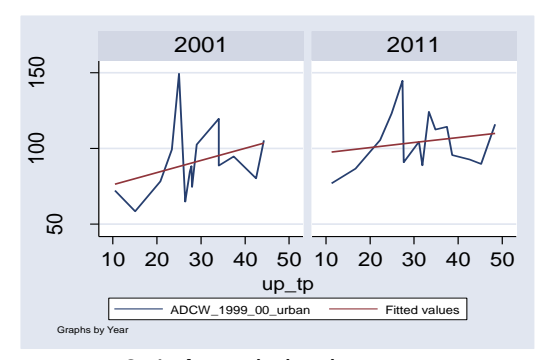

2.4. Association between

Wage-Rate-Urban and Urban-Level

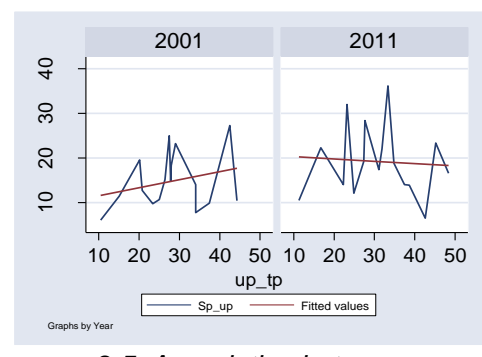

2.5. Association between

Slum-Level and Urban-Level

Fig. 2 - The relationships between the economic indicators and the level of urban population

Source: the authors' estimation ${ }^{13}$ 
The line diagram shows positive relationships between the Cost of living in urban and the Urban-Level in 2001 and no correlation is found between the Cost of living in urban and the Urban-Concentration in that year. However, positive relationships have been noticed and the relationships got starkly positive with both level and concentration of urban population in 2011. It denotes that the recent process of urbanisation inflates the cost of living.

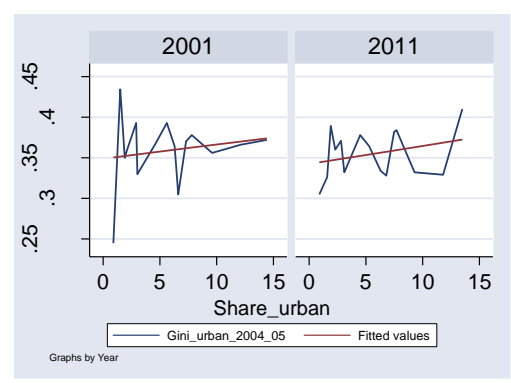

3.1. Association between UrbanEconomic-Inequality and UrbanConcentration

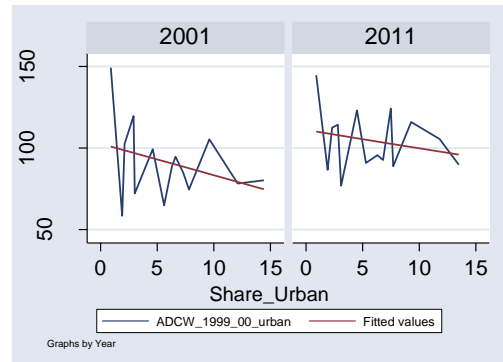

3.4. Association between Wage-RateUrban and Urban-Concentration

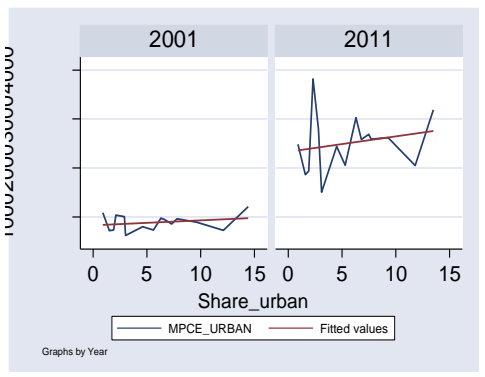

3.2. Association between Cost-ofLiving-Urban and Urban-Concentration

For all charts, X-axis: UrbanConcentration

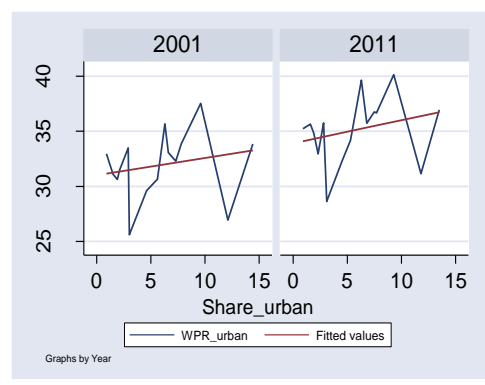

3.3. Association between UrbanEmployability and UrbanConcentration

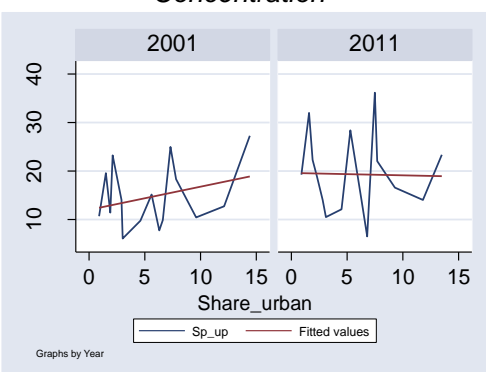

3.5. Association between Slum-Level and Urban-Concentration

Fig. 3-The relationships between economic indicators and the concentration of urban population

Source: the authors' estimation

The line diagram shows that employability in urban areas has increased with an increase in the level and concentration of the urban population. Moreover, those relationships in both years are sharply positive.

\section{Correlation results of urban population}

Table 4

\begin{tabular}{|c|c|c|c|c|c|c|}
\hline \multirow[t]{2}{*}{ Correlation results } & \multicolumn{2}{|c|}{ Urban-Level } & \multirow{2}{*}{$\begin{array}{l}\text { Difference } \\
\text { in } \\
\text { correlation }\end{array}$} & \multicolumn{2}{|c|}{$\begin{array}{c}\text { Urban- } \\
\text { Concentration }\end{array}$} & \multirow{2}{*}{$\begin{array}{l}\text { Difference } \\
\text { in } \\
\text { correlatior }\end{array}$} \\
\hline & 2001 & 2011 & & 2001 & 2011 & \\
\hline $\begin{array}{l}\text { Urban-Economic- } \\
\text { Inequality }\end{array}$ & 0.0172 & 0.1198 & 0.102 & 0.1636 & 0.2766 & 0.113 \\
\hline Cost-of-Living-Urban & $0.7310^{*}$ & $0.7305^{*}$ & -0.000 & 0.2496 & 0.2030 & -0.046 \\
\hline Urban-Employability & $0.8354^{*}$ & $0.7638^{*}$ & -0.071 & 0.2040 & 0.2640 & 0.060 \\
\hline Wage-Rate-Urban & 0.3242 & 0.1868 & -.1374 & -0.3223 & -0.2261 & .0962 \\
\hline Slum-Level & 0.2639 & -0.0674 & -.3313 & 0.2931 & -0.0241 & -.3172 \\
\hline
\end{tabular}

Source: the authors' estimation 
The wage rate in the urban is declining with the increase in the Urban-Concentration in both periods. However, the relationship between the Wage rate and the Urban-Level was positive in 2001, but no relation is observed between them in 2011.

In 2011, no relationship is found between the level of slum and urban population, as well as with the concentration of urban population, and the relationships have deteriorated over time which indicates that the expansion of the slum is not strongly dependent on the UrbanConcentration. There could be other factors influencing the expansion of slums (discussed in the next section). Moreover, one reason could be the high convertibility of land from rural to urban, which generates more urban population at once. Such newly formed urban hamlets do not draw the poor in those areas so quickly as those newly formed hamlets that are very much connected to the rural hinterlands, which are easy to commute. According to the Government of India (2011), the growth rate of town population is higher compared to that of slum population.

For knowing the process of urbanisation more deeply, we also looked into some other relations (Appendix 2). We found increasing positive relationships between the Cost-ofLiving-Urban and the Urban-Economic-Inequality, which possibly identifies inequality as a factor behind the rise in the cost of living. There is also an increasing positive relation between the Cost-of-Living-Urban and the Urban Economic Growth.

\section{Relationship between the level and concentration of slum population and the economic indicators}

The above-mentioned economic indicators might induce the increase in the concentration and level of slum population in urban areas. The increasing economic inequality has exacerbated a few people's wealth and income, making large sections of the population poor, property-less and incapable to get out of the slum. In contrast, the rise in the price level of goods, including the housing price and the price of services due to the growing demand of the rich, may inflate the cost of living for the poor. This may compel people to stay in slums/slum-like settlements; and this might be increasing the slum population.

Most of the workers in the urban areas are informal and low paid, while they mostly reside in slums. So, the rising informal employment in urban areas may lead to an increase in the slum population. Moreover, due to the rural-urban wage rate difference, a large chunk of the rural population migrates to urban areas every year (Lewis 1954) and it gets absorbed in informal works, thereby impacting the expansion of the slum. Therefore, we hypothesise positive relations with the economic indicators.

Here also, we consider both the level and concentration of the slum population to see the relationships with the economic indicators separately. Both the level and concentration of the slum population has a positive relationship with urban economic inequality. As described above, there is a tendency of increasing economic inequality with urbanisation, which depresses the capacity of the slum dwellers to come out of the slum (Fig. 4, Fig. 5, Table 5). Apart from this result, a positive relationship between urban economic growth and the concentration of slum population (Appendix 3 ) ratifies the fact of exclusionary urbanisation.

Furthermore, the level and concentration of slum population have positive relationships with the cost of living in urban in 2001. However, we find no relationship between the cost of living and the level of slum population in 2011. Although the cost of living has a positive relationship with the concentration of the slum, that is reduced over time. This indicates that living costs do not influence the generation of slum population. 


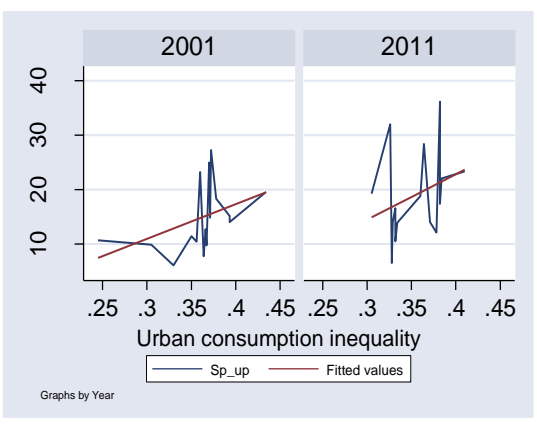

4.1. Association between Slum-Level and Urban-Economic-Inequality

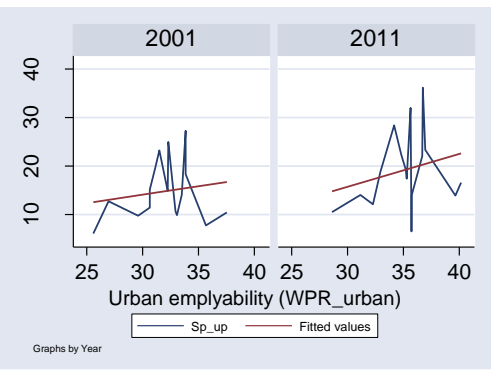

4.3. Association between Slum-Level and Urban-Employability

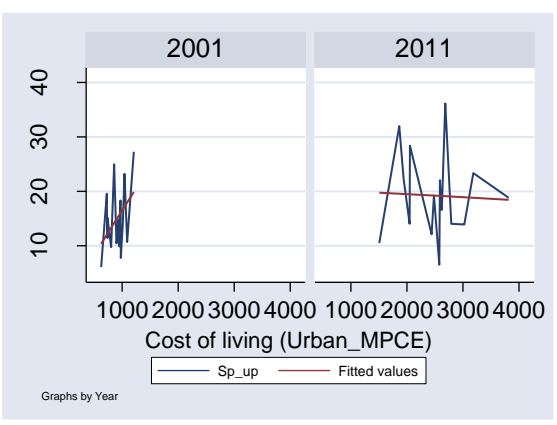

4.2. Association between Slum-Level and Cost-of-Living-Urban

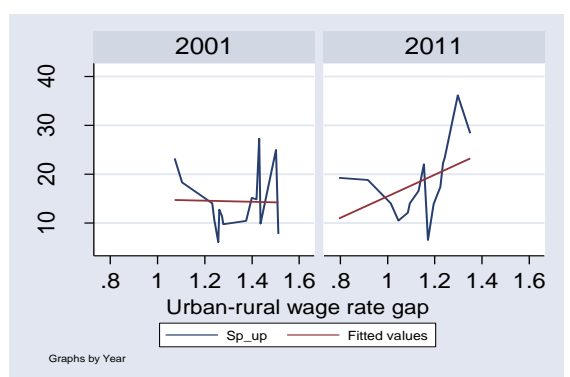

4.4. Association between Slum-Level and Urban-rural-Wage-Rate-Gap

Fig. 4 - The relationships between the level of slum population and economic indicators

Source: the authors' estimation

Correlation results of slum population

\begin{tabular}{|c|c|c|c|c|c|c|}
\hline \multirow{2}{*}{ Correlation results } & \multicolumn{2}{|c|}{ Slum-Level } & \multirow[t]{2}{*}{$\begin{array}{l}\text { Difference } \\
\text { in } \\
\text { Correlation }\end{array}$} & \multicolumn{2}{|c|}{$\begin{array}{c}\text { Slum- } \\
\text { Concentration }\end{array}$} & \multirow[t]{2}{*}{$\begin{array}{l}\text { Difference } \\
\text { in } \\
\text { Correlation }\end{array}$} \\
\hline & 2001 & 2011 & & 2001 & 2011 & \\
\hline Urban-Economic-Inequality & 0.2135 & $0.5272^{*}$ & 0.313 & $0.4197^{*}$ & 0.3150 & -0.104 \\
\hline Cost-of-Living-Urban & $0.4401^{*}$ & 0.2267 & -0.213 & $0.4098^{*}$ & -0.0399 & -0.449 \\
\hline Urban-Employability & 0.1991 & $0.3321^{*}$ & 0.133 & 0.1650 & 0.2494 & 0.165 \\
\hline Urban-rural-Wage-Rate-Gap & 0.3153 & $0.6060^{*}$ & 0.290 & -0.0265 & $0.4329^{*}$ & 0.406 \\
\hline
\end{tabular}

Source: the authors' estimation

The level and concentration of slum population have positive relationships with urban employability in both years. The Urban-rural wage rate gap is positively related with the level and concentration of the slum population in both periods as well. This explicates that the growth in size of the slum population is due to the expansion of informal employment and because of wage rate differences. The Urban-rural wage-rate gap pulls the poor workers to the urban areas and these migrants get involved mainly in informal work and they reside in slums. 


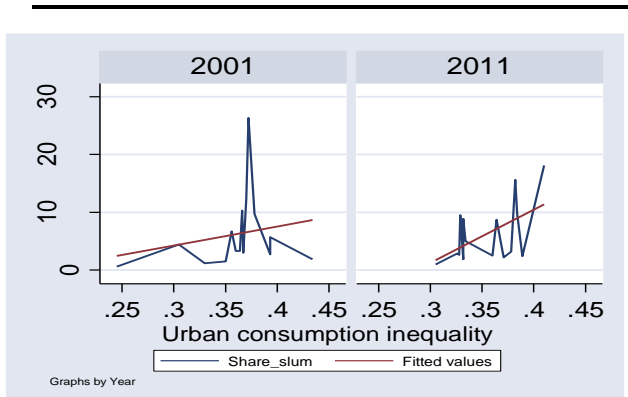

5.1. Association between Slum-Concentration and Urban-Consumption-Inequality

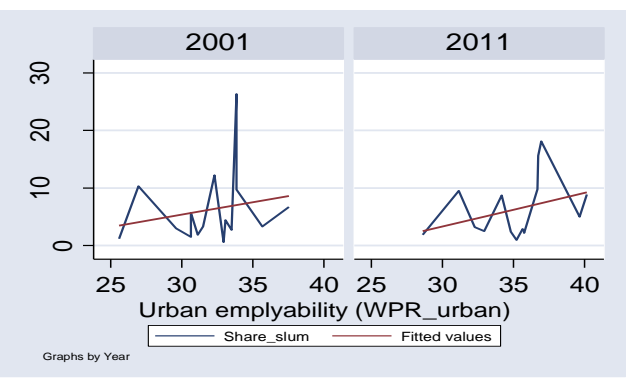

5.3. Association between Slum-

Concentration and Urban-Employability

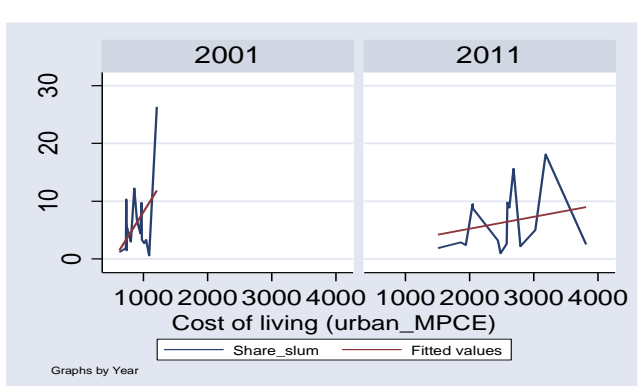

5.2. Association between Slum-Concentration and Cost-of-Living-Urban

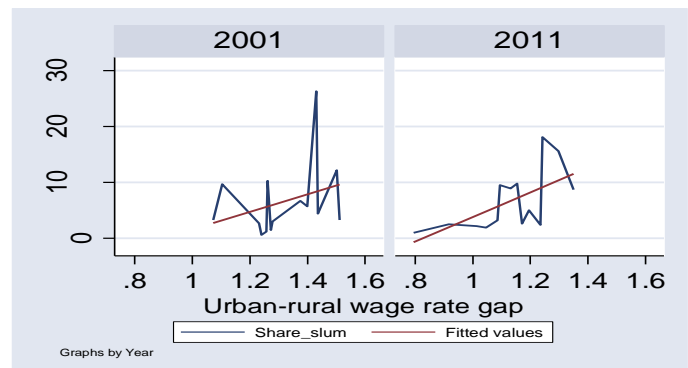

5.4. Association of Slum-Concentration with Urban-rural-Wage-Rate-Gap

Fig. 5- The relationships between the concentration of the slum population and economic indicators

Source: the authors' estimation

Regression analysis: the effect of economic factors on the level and concentration of slum population

One of the fundamental issues of this paper is to verify the probable impact of urban economic inequality on the expansion of the size of slum population. We have considered two regression models to validate such a claim. Here, for the regression analysis, we assume that the level and concentration of the slum population are the desired dependent variables (Table 6). But the variable 'level of slum population' is a ratio between the slum and the urban population which are highly correlated to each other. Such correlations between the numerator and the denominator dampen the variability of the variable 'level of slum population'. So, instead of considering the level of slum population, we considered the slum population as the dependent variable in the first model. In the second model, we assume the concentration of slum population as the dependent variable. We take 'logs' on both sides of the equations to eliminate the non-normality of the dependent variables (Appendix 4) and the problem of heteroscedasticity in the models. The independent variables are the urban economic inequality, the share of informal workers out of the total urban workers (as a control factor), the workforce participation rate in the urban, the share of total state population out of the total population of India, and the urban-rural wage rate gaps. We eliminate the Cost of Living from the equations as we found no such relation with both the level and the concentration of the slum population in the previous section. So, the regression equations are as follows:

$Y=a+b_{1} X_{1}+b_{3} X_{3}+b_{4} X_{4}+b_{5} X_{5}+b_{6} X_{6}+D_{1}+U$

$Z=a+b_{2} X_{2}+b_{3} X_{3}+b_{4} X_{4}+b_{5} X_{5}+b_{6} X_{6}+D_{1}+U$ 
Where $Y=\log ($ slum population) and $Z=\log ($ concentration of slum population)

$\mathrm{X}_{1}=\log ($ urban population)

$X_{2}=\log$ (share of total population of the state out of total population of India)

$X_{3}=\log$ (urban economic inequality)

$X_{4}=\log$ (share of urban informal workers out of total urban workers)

$X_{5}=$ Log(employment opportunity in urban)

$X_{6}=$ Log(urban-rural wage rate gaps)

$D_{1}=$ Time dummy (year $2001=0 ;$ year $2011=1$ )

Table 6

\begin{tabular}{|l|c|c|}
\hline \multicolumn{2}{|c|}{ Regression results } & \multicolumn{2}{c|}{ Dependent Variables } \\
\hline Independent variables & $Y$ & $Z$ \\
\hline$X_{1}$ & $.99132^{\star * *}$ & \\
\hline$X_{2}$ & & $1.0185^{\star * *}$ \\
\hline$X_{3}$ & $2.0319^{\star *}$ & $2.1865^{\star *}$ \\
\hline$X_{4}$ & -.36400 & -.00159 \\
\hline$X_{5}$ & 1.0039 & $4.6545^{\star * *}$ \\
\hline$X_{6}$ & -.20255 & -.48590 \\
\hline$D_{1}$ & .08106 & -.43996 \\
\hline Adjusted R-square & 0.8942 & 0.7264 \\
\hline Nos. of observation & 30 & 28 \\
\hline F-ratio (prob>F) & $41.86^{\star * *}$ & $12.95^{\star * *}$ \\
\hline Mean VIF & 1.67 & 1.93 \\
\hline Heteroscedasticity test (Chi-square sig) & 0.9155 & 0.6310 \\
\hline
\end{tabular}

Note: ${ }^{* *}$ and ${ }^{* * *}$ are the $5 \%$ and $1 \%$ level of significance

Source: the authors' estimation

The above regression shows that both models are robust as the R-square in the models are high and both of them are significant at $1 \%$ level. We found that urban economic inequality has a significant and positive impact on the growth of slum population and the growth of the concentration of slum population respectively, at $5 \%$ level of significance. These findings tentatively reveal that, economic inequality is a vital cause for expanding the size of the slum population in the city. The mean Variable Inflating Factors (VIF) in both results are low, indicating the absence of a serious multicollinearity problem. Besides, the Breusch-Pagan tests have been performed for verifying the heteroscedasticity problem in the models and they reveal insignificant chi-square results that denote that the assumption of homoscedasticity has prevailed.

\section{Discussion}

By summarising the above results, we could arrive to some propositions. First, we arrive at the proposition that the overall slum population is expanding at a higher rate compared to that of the urban population. Apart from Maharashtra, Gujarat and Haryana, the level of the slum population has increased in other better off and poor states. And a shift in the concentration of the slum population has been observed from the states of Gujarat and Maharashtra towards other highly growing states like Karnataka, TN and AP, pointing out an ongoing exclusionary urbanisation in most of the states. For the few states with a reduced level and concentration of the slum population, it is mostly due to inter-state migration and wage rate gaps, urbanism, eviction, growth of small-sized towns and extensive infrastructural development. On the contrary, for the states witnessing an increasing level 
and concentration of slum population, these are largely attributed to the unprecedented secondary and tertiary sectors-led growth in thriving urban centres accompanied by the poor urban planning and the intra-state migration.

Next, we find a positive association (correlation) of economic inequality with the concentration of urban population, whereas the former has indirect (positive) relation with the level of urban population through economic growth. It signifies that economic growth in urban areas has been playing a dual role. On one hand, it enhances the process of urbanisation through more investment or by creating more demand, and it generates inequality through improper distribution, on the other hand. The level of the urban population is positively related (line diagram) with the cost of living and the employment opportunity, but it is showing no relation with the urban wage rate. This signifies that the process of urbanisation has only created the option of a costlier living. A study (Kundu and Saraswati 2012) discusses the determinant of high urban cost of living: limited skilled jobs at urban centres generate high income for a small section who can spend exorbitantly. Along with this, a huge percentage of workers $(64.1 \%)$ are found to be crowded into informal enterprises with substandard income (National Statistical Office 2019). The wages in the informal sector have witnessed a very slow-paced rise over time (International Labour Organization 2018). This widening wage rate gap within urban areas is instrumental in not only raising but also in persisting urban economic inequality. Simultaneously, the concentration of the urban population is positively related (correlation) with employability, and it has an inverse relationship with the wage rate. This indicates a similar situation about the current urbanisation process as discussed above.

Then, we observe that the level and concentration of slum population are found to be positively associated (line diagram) with urban economic inequality, employability and urban-rural wage rate gaps. The significant positive impact (regression) of economic inequality on both slum population and its concentration is one of the reasons that helps slums to persist and exclusionary urbanisation to continue. Economic inequality helps to stretch the rich-poor gap, specifically in terms of the capacity of spending. So, the rising urban cost of living with little or no change in the earnings force the slum dwellers in India to live in slums for generation after generation (Marx et al. 2013). Moreover, another study shows (Krishna et al. 2014) that the prevailing inequality and the rising cost of living have deteriorated the situation of the new migrants into the cities. Besides, the growing urbanrural wage rate gap are still drawing the migrants from rural to the urban areas for a better wage, while they take shelter at slums. Supporting this fact, a study (International Labour Organization 2018) finds that the urban casual wage rate remains more than double than that of the rural over time.

The relationship between the different indicators as discussed above is encapsulated in the following flow chart below (Fig. 6). 


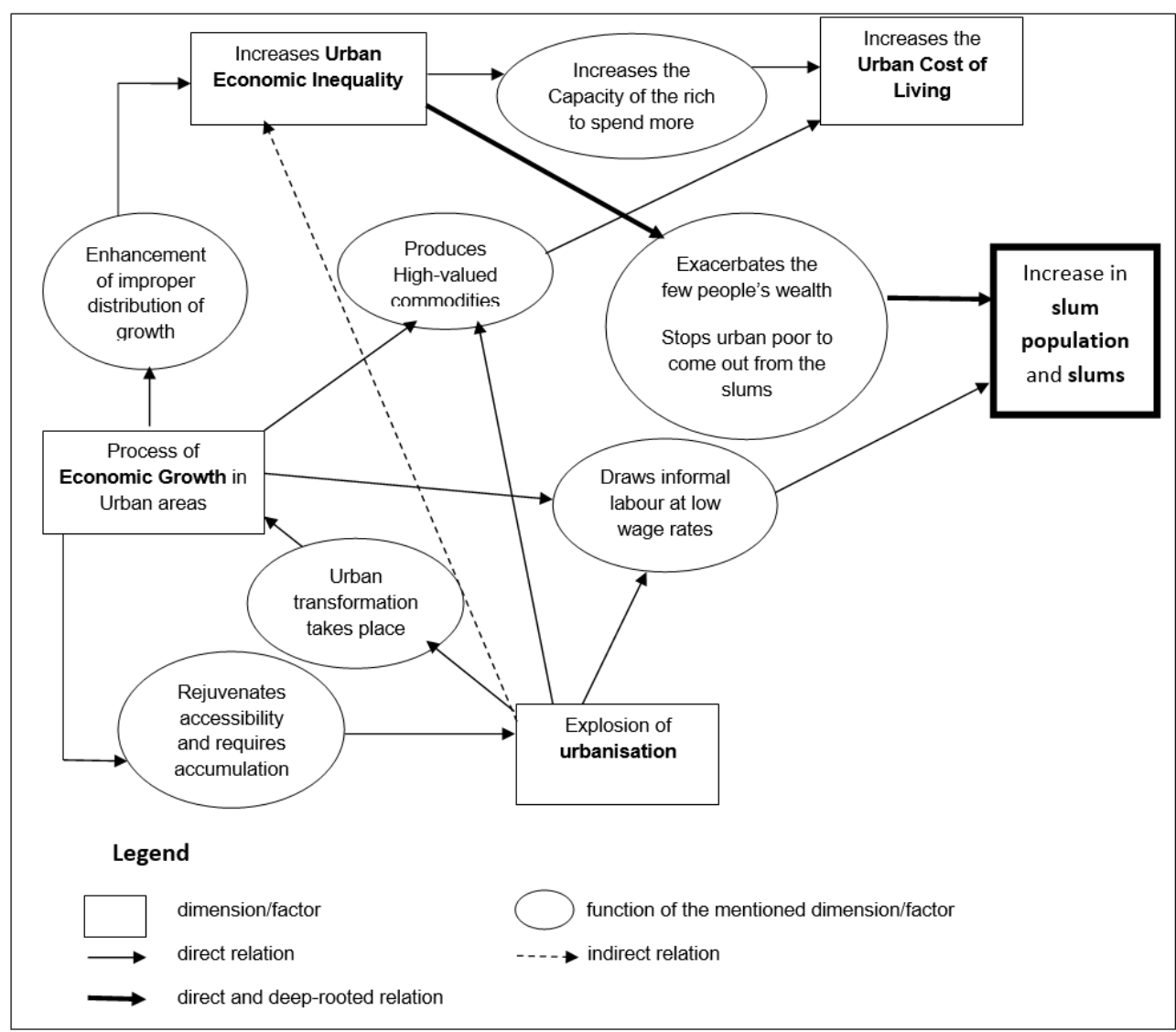

Fig. 6-Schematic flow chart of relationships of the proposed indicators

\section{Conclusions}

Throughout this paper, the analysis identifies an ongoing exclusionary process of urbanisation in India in terms of level, concentration and growth of slum population and its relationship with the economic indicators, which is shown in contrast to that of the urban population. Therefore, from the above discussion, it can be deduced that the crux of the problem is perhaps the exclusionary process of urbanisation which enhances the improper distribution of growth benefits. The sector-specific economic growth channelizes the fund, and it increases the demand for specific employment only. Besides, the new era of urban transformation makes a stark distinction in the wages between the skilled and the unskilled workers which leads to inequality, raising the burden of the cost of living on the urban poor. However, the process of urban transformation employs a large number of informal workers, who mostly migrate from the rural areas due to urban-rural wage differences, for restructuring the cities; but it pays diminishing wages to them because of huge unskilled labour supply, consequently widening inequality. Moreover, establishing world-class cities, along with world-class amenities at high prices, is perpetuated as per the requirement of the rich, which, again, increases the burden of the cost of living for the poor which resist them to shift in the better places of the city.

The Government's vision of attaining inclusive urbanisation through the creation of housing programs for the slum dwellers, like the 'Slum Free Cities' and 'Housing for All', is no doubt 
essential for providing free housing or housing at a subsidised rate to the urban poor. But it can contribute only a little in establishing inclusive urbanisation because the improper distribution of growth benefits and the sector-specific employment generation may offset such initiatives and they can enhance exclusionary urbanisation.

\section{Notes}

1. More than $60 \%$ of the total economic growth is contributed by urban areas (Buckley et al. 2007).

2. According to the Government of India (2011), the urban population has increased from 290 million in 2001 to 360 million in 2011.

3. During the 1990s and early 2000s, following the recommendation of United Nations for the upgradation and up-scale of urban slums for effective slum and urban development, the Government had taken up policies like: National Slum Development Programs, SJSRY, VAMBAY, etc. Later, the Government introduced policies like: Rajiv Awas Yojna, IBHUB, etc., for a comprehensive and inclusive urban development.

4. According to their population (Government of India 2011), Indian cities are classified tier-wise. Tier-I cities: 0.1 million or above population, Tier-ll cities: 50,000-99,999 population.

5. In India, a policy, namely VISION 2020, was introduced by the State Government of Maharashtra to restructure and redevelop Mumbai for making it an international city. This inflicts the eviction of many slum residents from the inner-city space to the fringes, at precarious conditions.

6. India is administratively divided into 28 states and 8 union territories. We use the acronyms of states as described: Jammu \& Kashmir - J\&K, Uttar Pradesh - UP, West Bengal - WB, Andhra Pradesh - AP, Tamil Nadu - TN, Madhya Pradesh - MP.

7. and 8. Urban Wage/Urban-Rural Wage-Rate Gap represents the average wage/salary earnings per day received by the casual labour mostly engaged in informal works.

9. The authors have estimated the data from the census (Government of India 2001, Government of India 2011).

10. Urbanism: adopting urban ways of living within the villages or the suburbs.

11. Class Tier-III towns are increasing at a rate of $31.3 \%$ compared to $8.2 \%$ for Tier-I and $10 \%$ for Tier-II towns in Maharashtra (Government of India 2011).

12. One in every six urban Indian lives in the slums and 65\% towns in India have slums (DownToEarth 2019).

13. The authors used the sources given in Table 1 for collecting the data. It is the same for all the other figures and tables.

\section{References}

AKBAR P. A., COUTURE V., DURANTON G., STOREYGARD A. (2018), Mobility and Congestion in Urban India, National Bureau of Economic Research, Retrieved from: www.nber.org.

AHMED W., KUNDU A., PEET R. (2011), India's New Economic Policy: A Critical Analysis, Routledge, New York.

ARMENDARIS F. (2015), World - Inclusive cities approach paper, World Bank Group, Retrieved from: www.documents.worldbank.org.

BHATKAL T., AVIS W., NICOLAI S. (2015), Towards a Better Life? A cautionary tale of progress in Ahmedabad, Overseas Development Institute, Retrieved from: www.gwp.org.

BUCKLEY R. M., SINGH M., KALARICKAL J. (2007), Strategizing Slum Improvement in India: A Method to Monitor and Refocus Slum Development Programs, Global Urban Development Magazine 3 (1), 1-24.

CHAUVIN J. P., GLAESER E., MA Y., TOBIO K. (2017), What is different about urbanization in rich and poor countries? Cities in Brazil, China, India and the United States, Journal of Urban Economics 98, 17-49.

CHAKRABARTI S. (2016), Inclusive Growth and Social Change: Formal-InformalAgrarian Relations in India, Oxford University Press, Oxford.

DAVIS K. (1965), The Urbanization of the Human Population, Scientific American $213(3), 40-53$ 
Somenath GHOSH, Pallabi SETH, Saumya CHAKRABARTI ${ }^{1}$

DOWNTOEARTH (2019), Slumming it out, Retrieved from:

www.downtoearth.org.in.

DUFLO E., GALIANI S., MOBARAK M. (2012), Improving Access to Urban Services for the Poor: Open Issues and a Framework for a Future Research Agenda, J-PAL, Retrieved from: www.povertyactionlab.org.

EDWIN T. (2019), Migrants seem to prefer neighbouring States for livelihood, The Hindu Business line, Retrieved from: www.thehindubusinessline.com. FOX S. (2014), The Political Economy of Slums: Theory and Evidence from SubSaharan Africa, World Development 54, 191-203. FRANKENHOFF C. A. (1967), Elements of an Economic Model for Slums in a Developing Economy, Economic Development and Cultural Change 16 (1), 27-36. GLAESER E. (2011), Triumph of the City: How Our Greatest Invention Makes Us Richer, Smarter, Greener, Healthier, and Happier, Penguin Press, New York. GOVERNMENT OF INDIA (2001), Primary Census Abstract, Urban and Slum Population, Retrieved from: www.censusindia.gov.in. GOVERNMENT OF INDIA (2011), Primary Census Abstract, Urban and Slum Population, Retrieved from: www.censusindia.gov.in. HARRIS J. R., TODARO M. P. (1970), Migration, Unemployment and

Development: A Two-Sector Analysis, The American Economic Review 60 (1), 126-142. HARVEY D. (2008), The Right to the City, New Left Review 53, 23-40. HENDERSON J. V., TURNER M. A. (2020), Urbanization in the Developing World: Too Early or Too Slow?, Journal of Economic Perspectives 34 (3), 150-173. HOUSING AND LAND RIGHTS NETWORK (2014), Forced to the Fringes: Disasters of 'Resettlement' in India. Report Three. Vashi Naka, Mumbai, Housing and Land Rights Network, New Delhi. INDIAN INSTITUTE FOR HUMAN SETTLEMENTS (2014), Cities as Engines of Inclusive Development: IIHS-RF paper on Indian Urban Economy, Retrieved from: www.iihs.co.in INTERNATIONAL LABOUR ORGANIZATION (2018), India Wage Report: Wage policies for decent work and inclusive growth, International Labour Organisation, Geneva. JOHN P. (2019), In 10 years, 79\% rise in migration to Gujarat's urban areas, The Times of India, Retrieved from: www.timesofindia.indiatimes.com. KOLAPPAN B. (2016), What drives urbanisation in Tamil Nadu, The Hindu, Retrieved from: www.thehindu.com.

KRISHNA A., SRIRAM M. S., PRAKASH P. (2014), Slum types and adaptation strategies: identifying policy-relevant differences in Bangalore, Environment and Urbanization 26 (2), 568-585.

KUNDU D., SAMANTA D. (2011), Redefining the Inclusive Urban Agenda in India Economic \& Political Weekly 46 (5), 55-63.

KUNDU A., SARASWATI L. R. (2012), Migration and Exclusionary Urbanisation in India, Economic \& Political Weekly 47 (26/27), 219-227.

LAHIRI A. (2016), West Bengal from an external perspective, Ideas for India, Retrieved from: www.ideasforindia.in.

LALL S. V., HENDERSON J. V., VENABLES A. J. (2017), Africa's Cities: Opening Doors to the World, The World Bank, Washington, D.C.

LEWIS W. A. (1954), Economic Development with Unlimited Supplies of Labor,

The Manchester School 22 (2), 139-191. MARX B., STOKER T., SURI T. (2013), The Economics of Slums in the Developing

World, Journal of Economic Perspectives 27 (4), 187-210. MAZUMDAR D. (1976), The urban informal sector, World Development 4 (8), 655679.

MISHRA A. K., DASGUPTA S. (2014), Evolution of National Policies for Affordable Housing and Basic Services for the Urban Poor, in: Ministry of Housing and Urban Poverty Alleviation, Government of India (ed.), Inclusive Urban Planning: State of the Urban Poor Report 2013, Oxford University Press, New Delhi, pp. 3-23. 
MUKHERJEE D. (2007), Post-Reform Trends in Wage Differentials: $A$ Decomposition Analysis for India, Indian Journal of Labor Economics 50 (4), 955-965.

NATIONAL SAMPLE SURVEY OFFICE (2011), Employment and Unemployment Situation in India (2009-10), National Sample Survey Office, National Statistical Organisation, Ministry of Statistics and Programme Implementation, Government of India, Retrieved from: www.mospi.nic.in.

NATIONAL SAMPLE SURVEY OFFICE (2014), Household Consumption of Various Goods and Services in India (2011-12), National Sample Survey Office, Ministry of Statistics and Programme Implementation, Government of India, Retrieved from: www.mospi.nic.in.

NATIONAL SAMPLE SURVEY ORGANISATION (2001a), Employment and Unemployment Situation in India (1999-2000), National Sample Survey Organisation, Ministry of Statistics and Programme Implementation, Government of India, Retrieved from: www.mospi.nic.in.

NATIONAL SAMPLE SURVEY ORGANISATION (2001b), Non-agricultural workers in informal sector based on Employment - Unemployment survey (1999-2000), National Sample Survey Organisation, Ministry of Statistics and Programme Implementation, Government of India, Retrieved from: www.mospi.nic.in.

NATIONAL SAMPLE SURVEY ORGANISATION (2003), Household Consumer Expenditure and Employment - Unemployment Situation in India (2001-2002), National Sample Survey Organisation, Ministry of Statistics and Programme Implementation, Government of India, Retrieved from: www.mospi.nic.in.

NATIONAL SAMPLE SURVEY ORGANISATION (2012), Informal Sector and Conditions of Employment in India (2009-2010), National Sample Survey Office, National Statistical Organisation, Ministry of Statistics and Programme Implementation, Government of India, Retrieved from: www.mospi.nic.in.

NATIONAL STATISTICAL OFFICE (2019), Annual Report: Periodic Labour Force Survey (2017-2018), National Statistical Office, Ministry of Statistics and Programme Implementation, Government of India, Retrieved from: www.mospi.nic.in.

PIEL G. (1997), The Urbanization of Poverty Worldwide, Challenge 40 (1), 58-68.

PLANNING COMMISSION OF INDIA (2014), Gini Coefficient of Distribution of Consumption: 1973-74 to 2009-10, Planning Commission of India, Government of India, Retrieved from: www.niti.gov.in.

RESERVE BANK OF INDIA (2021), Handbook of Statistics on Indian States, Government of India, Reserve Bank of India, Retrieved from: www.rbi.org.in.

ROHIT P. S. (2013), Steep rise in Hyderabad's slum population, The Times of India, Retrieved from: www.timesofindia.indiatimes.com.

ROY A. (2014), The Inclusive City: A New Paradigm of Urban Planning in India, in: Ministry of Housing and Urban Poverty Alleviation, Government of India (ed.), Inclusive Urban Planning: State of the Urban Poor Report 2013, Oxford University Press, New Delhi, pp. 134-148.

SANKHE S., VITTAL I., DOBBS R., MOHAN A., GULATI A., ABLETT J., GUPTA S., KIM A., PAUL S., SANGHVI A., SETHY G. (2010), India's urban awakening: Building inclusive cities, sustaining economic growth, McKinsey Global Institute, Retrieved from: www.mckinsey.com.

SARKAR S., MEHTA B. S. (2010), Income Inequality in India: Pre- and Post-

Reform Periods, Economic and Political Weekly 45 (37), 45-55.

SENGUPTA A., KANNAN K. P., RAVEENDRAN G. (2008), India's Common

People: Who Are They, How Many Are They and How Do They Live?, Economic and Political Weekly 43 (11), 49-63.

SINGH P., SINGH B. (2014), Structure and Pattern of Urbanisation in Punjab: A

Macro Level Analysis, Journal of Punjab Studies 21 (1), 69-89.

SINGH S., SINGH D. (2013), Urbanism vs Urbanization in Haryana: A Regional Analysis, International Journal of Environment, Ecology, Family and Urban Studies 3 (5), 1122.

STOKES C. J. (1963), A Theory of Slums, Ekistics 15 (88), 121-124. 
TACOLI C., MCGRANAHAN G., SATTERTHWAITE D. (2015), Urbanisation, ruralurban migration and urban poverty, International Institute for Environment and Development, London.

TURNER J. F. C. (1969), Uncontrolled Urban Settlement: Problems and Policies, in: Breese G. (ed.), The City in Newly Developing Countries: Readings on Urbanism and Urbanization, Prentice Hall, Engelwood Cliffs, pp. 507-534.

UN-HABITAT (2003), The Challenges of Slums: Global Report on Human Settlements 2003, Earthscan, London.

UN-HABITAT (2009), Planning Sustainable Cities: Global Report on Human Settlements 2009, Earthscan, London.

UN-HABITAT (2013), State of the World's Cities 2012/2013: Prosperity of Cities, Routledge, London.

WORLD BANK (2009), World Development Report 2009: Reshaping Economic Geography, The World Bank, Washington, D.C.

WORLD BANK (2013), Urbanization beyond municipal boundaries: nurturing metropolitan economies and connecting peri-urban areas in India, The World Bank, Washington, D.C.

Initial submission: 28.05.2020

Revised submission: 29.09.2020

Final acceptance: 19.10 .2020

Correspondence: Fondazione L'Albero Della Vita, India Country Office - 1241, Hossainpur Road, Madurdaha Kolkata-700107, West Bengal, India.

Email: pallabi.seth@gmail.com 


\section{Appendix 1}

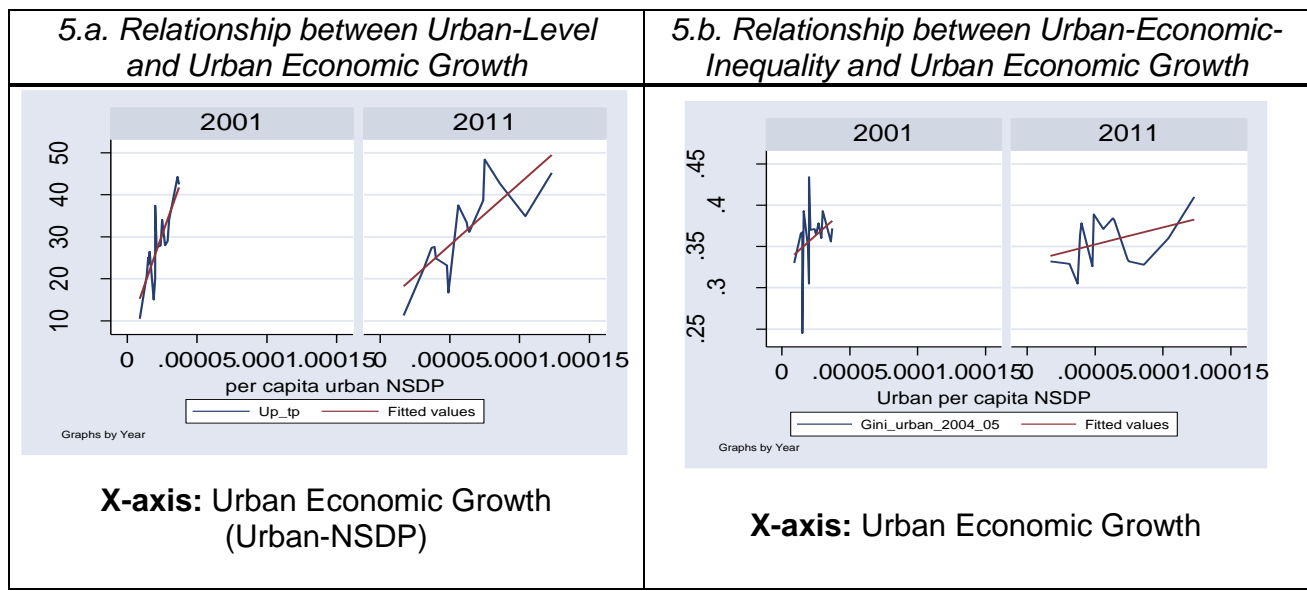

Source: the authors' estimation

Correlation results: Urban Economic Growth Urban-Level and Urban-Economic-Inequality

\begin{tabular}{|l|c|c|c|c|}
\hline \multirow{2}{*}{ Correlation results } & \multicolumn{2}{|c|}{ Urban-Level } & \multicolumn{2}{c|}{ Urban-Economic-Inequality } \\
\cline { 2 - 5 } & $\mathbf{2 0 0 1}$ & $\mathbf{2 0 1 1}$ & $\mathbf{2 0 0 1}$ & $\mathbf{2 0 1 1}$ \\
\hline Urban Economic Growth & 0.8234 & 0.7962 & 0.2817 & 0.3811 \\
\hline
\end{tabular}

Source: the authors' estimation

Here, Urban Economic Growth has been estimated by multiplying the per capita NSDP with the ratio of the urban-rural consumption expenditure. The above result shows that UrbanNSDP is positively related to both Urban-Level and Urban-Economic-Inequality. This may imply that the expanding urbanisation is a result of urban-centric economic growth, and the process of urbanisation has helped the economy to grow. But the benefits of growth have been skewed to few hands and they may result in increased inequality in the urban areas. So, the circuitously urban inequality is highly related to the process of urbanisation.

\section{Appendix 2}

Table 8

Correlation Results: Urban-Economic Inequality, Urban-NSDP and Cost-of-Living-Urban

\begin{tabular}{|l|l|c|}
\hline \multirow{2}{*}{ Correlation results } & \multicolumn{2}{c|}{ Cost-of-Living-Urban } \\
\cline { 2 - 3 } & $\mathbf{2 0 0 1}$ & $\mathbf{2 0 1 1}$ \\
\hline Urban-Economic-Inequality & -0.2654 & 0.2879 \\
\hline Urban-NSDP & 0.6955 & 0.8297 \\
\hline
\end{tabular}

Source: the authors' estimation 


\section{Appendix 3}

\section{Urban-NSDP and Slum-Concentration}

Table 9

\begin{tabular}{|l|c|c|}
\hline \multirow{2}{*}{ Correlation results } & \multicolumn{2}{|c|}{ Slum-Concentration } \\
\cline { 2 - 3 } & $\mathbf{2 0 0 1}$ & $\mathbf{2 0 1 1}$ \\
\hline Urban-NSDP & 0.5070 & 0.4080 \\
\hline
\end{tabular}

Source: the authors' estimation

\section{Appendix 4}

The distribution of the level and concentration of the slum population with the help of the histogram and the normal curve below shows the distributions are not normal and they are skewed leftward. So, to make the distributions normal, we have taken log of dependent variables.

6.a. Distribution of Slum Population

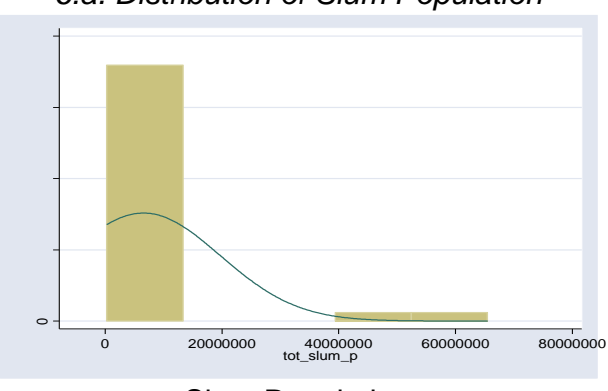

Slum Population

6.c. Distribution of Concentration of slum population

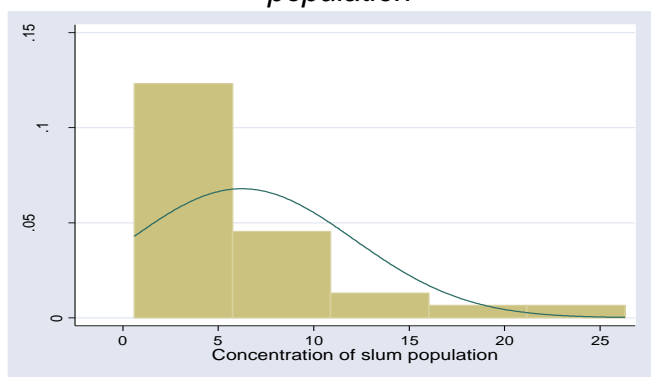

6.b. Distribution of Log Slum Population

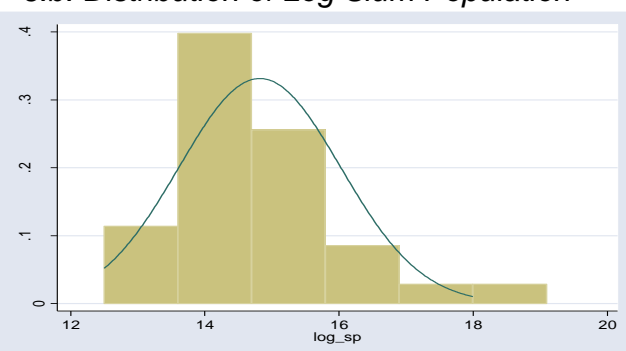

Log Slum Population

6.d. Distribution of Log Concentration of slum population

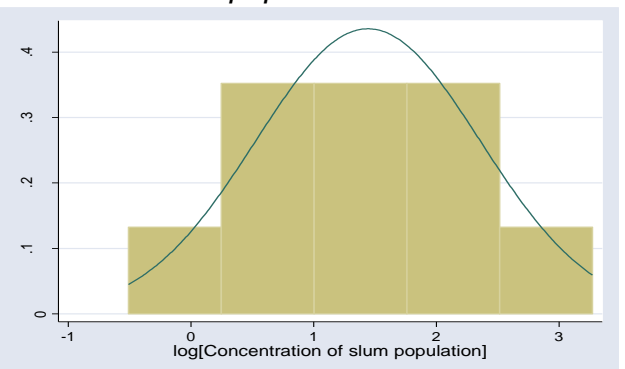

Source: the authors' estimation 